\title{
Ka

\section{Pemberian Karang Memadu Sebagai Sanksi Adat Untuk Mencegah Poligami di Desa Adat Panglipuran}

\author{
I Nyoman Putu Budiartha, I Wayan Suka Wirawan dan I Nyoman Srimurti \\ Magister Ilmu Hukum Pascasarjana Universitas Warmadewa, Denpasar, Bali-Indonesia \\ budiarthaputu59@gmail.com
}

Published: 30/01/2021

How To Cite:

Budiartha, I. N. P., Wirawan, I. W. S., \& Srimurti, I. N (2021). Pemberian Karang Memadu Sebagai Sanksi Adat Untuk Mencegah Poligami di Desa Adat Panglipuran. KERTHA WICAKSANA: Sarana Komunikasi Dosen dan Mahasiswa. 15(1). Pp 54-61. https://doi.org/10.22225/kw.15.1.2806.54-61

\begin{abstract}
Abstrak
Pemberian lahan "Tanah Karang Memadu" bagi mereka yang melakukan perkawinan poligami di Desa Adat Pengelipuran, Bangli adalah bentuk sanksi adat dari kearifan lokal setempat yang wajib dilestarikan. Sanksi adat ini telah terbukti mampu mencegah niat masyarakat untuk melakukan poligami. Dalam Undang-undang Nomor 1 Tahun 1974 yang sudah diubah dengan Undang-undang Nomor 16 Tahun 2019 tentang Perkawinan, ditegaskan bahwa perkawinan adalah ikatan lahir batin antara seorang laki-laki dengan seorang perempuan. Jadi asas yang dianut adalah asas monogami. Namun demikian tidak sedikit masyarakat karena alasan tertentu melakukan perkawinan poligami atau mempunyai lebih dari satu orang istri. Secara normatif, masyarakat adat Desa Penglipuran memandang berpoligami itu sebagai pelanggaran norma adat. Karena itulah bagi mereka yang berani melakukan poligami dikenakan sanksi keluar dari pekarangan desa, lalu diberikan tempat yang disebut sebagai "Karang Mamadu". Penelitian ini menjawab permasalahan, bagaimanakah pelaksanaan sanksi adat Karang Memadu di Desa Penglipuran, dan apakah sanksi adat Karang Memadu terlaksana dengan efektif di Desa Adat Penglipuran. Jenis penelitian yang akan dipergunakan dalam jenis penelitian hukum emperis. Temuan hasil penelitian membrikan penegasan bahwa pemberian "Karang Memadu" adalah salah satu bentuk sanksi adat yang mempunyai implikasi hukum sangat singinifian dalam rangka mencegah terjadinya perkawinan poligami atau "memadu". Indikasinya adalah, sampai penelitian ini selesai dilakukan sama sekali "karang memadu" yang dimaksud belum pernah dimanfaatkan oleh mereka yang melakukan perkawinan poligami. Saran yang dapat direkomenasikan adalah, sanksi pemberian"Karang Memadu" ini agar dilestarikan untuk menjamin keteraturan sosial.
\end{abstract}

Kata Kunci: Karang Memadu; Sanksi Adat; Pengelipuran; Poligami

\begin{abstract}
The granting of land "Tanah Karang Memadu" for those conducting polygamous marriages in Pengelipuran Traditional Village, Bangli is a form of customary sanction from local wisdom that must be preserved. This customary sanction has proven able to prevent the community's intention to practice polygamy. In Law Number 1 of 1974 which has been amended by Law Number 16 of 2019 concerning Marriage, it is emphasized that marriage is a physical and spiritual bond between a man and a woman. So the principle adopted is the principle of monogamy. However, many people for some reason have polygamous marriages or have more than one wife. Normatively, the adat community of Penglipuran Village views polygamy as a violation of customary norms. That is why those who dare to practice polygamy will be sanctioned to leave the village yard and then be given a place known as "Karang Mamadu". This research answers the problem, how is the implementation of Karang Memadu customary sanctions in Penglipuran Village, and whether the Karang Memadu customary sanctions are implemented effectively in Penglipuran Traditional Village. This type of research will be used in this type of empirical legal research. The findings of the research confirm that the provision of "Karang Memadu" is a form of customary sanction which has very significant legal implications in preventing the occurrence of polygamous or "Memadu" marriages. The indication is, until this research has been completed, the "Karang Memadu" in question has never been used by those who carry out polygamous marriages. Suggestions that can be recommended are, the sanction of giving this "Karang Memadu" is so that it is preserved to ensure social order.
\end{abstract}


Keywords: Karang Memadu; Customary Sanctions; Pengelipuran; Polygamy

\section{PENDAHULUAN}

Dalam hal mengekspresikan rasa cinta kasih dalam keluarga oleh suami terhadap istri, sering caranya bermacam-macam. Ada yang konsisten mengambil model perkawinan monogami, hanya dengan satu istri saja. Namun demikian tidak sedikit juga masyarakat yang memilih poligami atau mempunyai lebih dari satu istri. Berpoligami sebagai salah satu fenomena sosial dan hukum di masyarakat adalah hal yang sama sekali tidak aneh. Secara historis, kehidupan berpoligami sudah dilakukan sejak jaman dahulu oleh para penguasa (raja-raja), dan juga dilakukan oleh masyarakat biasa. Walaupun sangat lumbrah dilakukan, berpoligami selalu mendapat perlawanan dan penentangan dari kelompok masyarakat lainnya, terutama dari istri pertama dari rumah tangga yang berpoligami. Pada kelompok masyarakat tertentu, berpoligami atau seorang suami mempunyai dua atau lebih istri, juga berpoliandri, yaitu seorang istri mempunyai dua atau lebih suami justru menjadi kebanggaan tersendiri dan mendapatkan penghormatan tersendiri di masyarakat.

Namun demikian, apapun alasannya model perkawinan poligami secara sosial dan psikhologi bisa menyakiti baik pisik maupun mental pihak istri pertama, dan juga anak-anaknya. Hakekat dari diterbitkannya Undang-undang Nomor 1 Tahun 1974 yang sudah direvisi dengan Undangundang Nomor 16 Tahun 2019 tentang Perkawinan adalah untuk mempersulit pelaksanan perkawinan berpoligami dan mempersulit untuk terjadinya perceraian.

Di Desa Adat Penglipuran, Kelurahan Kubu, Kecamatan Bangli, Kabupaten Bangli, Provinsi Bali, berpoligami dianggap sebagai prilaku menyimpang dari norma dan dinilai melanggar hukum adat yang ditaati dan dihormati oleh masyarakat setempat. Karena itulah bagi masyarakat Desa Adat Penglipuran yang berani melakukan perkawinan poligami, maka dikenakan sanksi adat berupa pemindahan mempelai dari kawasan pemukiman ke kawasan lain yang relatif jauh dari desa setempat. Model sanksi adat ini dikenal sebagai upaya pencegahan poligami. Presedurnya, dengan diberikan lahan untuk tempat membangun rumah yang disebut sebagai "Karang Memadu". Secara etemologi karang artinya, "karang" artinya tanah atau lahan, dan "memadu" artinya berpoligami atau memiliki lebih dari satu istri. Kaum laki-laki tidak diperkenankan mengangkat istri lebih dari satu. Mereka yang melanggar aturan adat tidak bisa lagi tinggal bersama masyarakat di desa, melainkan diasingkan di Karang Memadu yang berada di selatan rumah penduduk (Maharani, 2017).

Pada penelitian sebelumnya, (Sattwika, Sudibya, \& Ujianti, 2020) mengungkapkan sistem perkawinan di Desa Adat Penglipuran adalah sama dengan sistem perkawinan pada masyarakat Bali pada umumnya yaitu mengambil pola ngidih (melamar) dan memaling. Hal yang unik dan menarik berkaitan dengan perkawinan adalah adanya penghormatan terhadap harkat martabat wanita sebagai seorang istri dijungjung tinggi dengan pengaturan larangan berpoligami bagi suami. Menjawab hasil Penelitian sattwika dkk, (Ardiani, 2015) mengungkapkan sanksi karang memadu di desa adat penglipuran dilakukan melalui tiga tahapan yaitu tahapan yang pertama adalah tahap pemanggilan pihak yang melakukan tindakan poligami, tahap kedua yaitu pembuatan gubug untuk keluarga yang melakukan tindakan poligami, sipelaku poligami akan dibuatkan sebuah gubug sebagai tempat tinggal mereka nantinya di sebuah lahan yang bernama "karang memadu", Tahap ketiga yaitu penempatan keluarga pelaku tindak poligami tersebut di gubug yang sudah dibuatkan oleh warga di areal karang memadu tersebut.

Berdasarkan uraian yang telah dijelaskan tersebut dan melihat pula kenyataan di lapangan maka dalam artikel ini penulis akan mengangkat dua permasalahan yang sangat disoroti yaitu yang pertama Bagaimanakah pelaksanaan sanksi adat Karang Memadu di Desa Adat Penglipuran? Dan kemudian akan dibahas juga mengenai Apakah sanksi adat Karang Memadu dapat dilaksanakan secara efektif di masyarakat Desa Adat Penglipuran?.

\section{METODE}

Jenis penelitian yang dipakai di dalam penelitian ini adalah jenis penelitian hukum sosiologis atau jenis penelitian yuridis emperis yang merupakan prosedur pemecahan masalah penelitian dengan cara meneliti data sekunder terlebih dahulu dan kemudian dilanjutkan dengan melakukan penelitian terhadap data primer dilapangan. Dalam penelitian hukum empiris, hukum dikonsepkan sebagai suatu gejala empiris 
yang dapat diamati dalam kehidupan nyata (Moelong, 2002). Penelitian hukum empiris dengan melakukan penelitian langsung ke lapangan (field research) merupakan pengumpulan data dengan studi kasus ke Desa Adat Penglipuran, Kelurahan Kubu, Kecamatan Bangli, Kabupaten Bangli. Penulis juga menggunakan pendekatan sosiologi yaitu hukum yang dikonsepkan sebagai gejala yang dapat diamati dalam kehidupan masyarakat dengan maksud dan tujuan untuk menemukan fakta (fact finding) yang kemudian menuju pada identifikasi (problem identification) dan akhirnya menuju pada penyelesaian masalah (problem solution).

\section{HASIL DAN PEMBAHASAN}

\section{Demografi Desa Adat Penglipuran}

Desa Penglipuran merupakan salah satu desa adat yang telah berkembang menjadi desa wisata yang sangat ramai dikunjungi para wisatawan, lokal maupun mancanegara. Bahkan, pada awal penetapannya desa ini sebagai desa wisata, turis asing-lah yang sering memadati desa yang terletak di Bangli ini.

Desa ini terkenal sebagai salah satu destinasi wisata di Bali karena masyarakatnya yang masih menjalankan dan melestarikan budaya tradisional Bali di kehidupan mereka sehari-hari. Sebagai salah satu desa tua di Bali, Arsitektur bangunan dan pengolahan lahan masih mengikuti konsep Tri Hita Karana, filosofi masyarakat Bali mengenai keseimbangan hubungan antara Tuhan, manusia, dan lingkungannya (Kasuma \& Suprijanto, 2012). Mereka berhasil membangun pariwisata yang menguntungkan seluruh masyarakatnya tanpa menghilangkan budaya dan tradisi mereka. Pada tahun 1995, Desa Penglipuran juga mendapatkan penghargaan Kalpataru dari Pemerintah Indonesia atas usahanya melindungi Hutan Bambu di ekosistem lokal mereka. Secara administratif, desa adat ini termasuk dalam wilayah Keluruhan Kubu, Kecamatan Bangli, Kabupaten Bangli. Total area dari desa ini mencapai 112 hektar dengan ketinggian 500-600 meter diatas laut dan berlokasi sekitar 5 kilometer dari kota Bangli atau 45 kilometer dari Kota Denpasar. Desa ini dikelilingi oleh desa adat lainnya, seperti Desa Kayang di utara, Desa Kubu di timur, Desa Gunaksa di selatan dan Desa Cekeng. Temperatur bervariasi dari sejuk sampai dingin $\left(16-29{ }^{\circ} \mathrm{C}\right)$ dan curah hujan rata-rata $2000 \mathrm{~mm}$ pertahun. Permukaan tanah termasuk rendah dengan ketinggian 1-15 meter.
Mengenai asal mulai kata Desa Penglipuran, ada 2 persepsi berbeda yang diyakini oleh masyarakatnya. Yang pertama adalah Penglipuran berarti "pengeling pura" dengan "pengeling" berarti ingat dan "pura" berarti tempat leluhur. Presepsi yang kedua mengatakan bahwa penglipuran berasal dari kata "pelipur" yang berarti hibur dan "lipur" yang berarti "ketidakbahagiaan". Jika digabungkan maka kata "penglipuran" berarti tempat untuk penghiburan. Persepsi ini muncul karena Raja Bangli pada saat itu dikatakan sering mengunjungi desa ini untuk bermeditasi dan bersantai.

\section{Desa Adat Penglipuran Sebagai Destinasi Pariwisata Berbasis Ekowisata}

Secara etimologis pariwisata berasal dari bahasa sansekerta, yang terdiri dari dua suku kata Pari yang berarti banyak, berkali-kali, berputarputar, lengkap. Dan kata wisata yang berarti perjalanan, bepergian yang bersinonim dengan kata travel dalam bahasa Inggris, maka dapat di artikan bahwa pariwisata adalah perjalanan yang dilakukan berkali-kali atau berputar-putar dari satu tempat ke tempat lain. Pariwisata adalah segala sesuatu yang berhubungan dengan wisata, termasuk pengusahaan objek dan daya tarik wisata serta usaha-usaha yang terkait di bidang tersebut.

Berdasarkan penelitian yang dilakukan, teridentifikasi ada beberapa tujuan orang melakukan perjalanan wisata, yaitu:

- Untuk menggunakan waktu senggang, baik rekreasi(berlibur), keperluan kesehatan, pelajaran dan pengetahuan, serta untuk menjalankan ibadah maupun olahraga

- Untuk keperluan usaha atau bisnis, kunjungan keluarga, menjalankan tugas tugas, serta menghadiri konferensi. Jika seseorang mengadakan perjalanan kurang dari 24 jam,

- Memperkenalkan, mendayagunakan, melestarikan dan meningkatkan mutu objek dan daya tarik wisata;

- Memupuk rasa cinta tanah air dan meningkatkan persahabatan antar bangsa;

- Memperluas dan memeratakan kesempatan berusaha dan lapangan kerja.

Pengertian Perkawinan, Poligami, dan Akibat
Poligami Perkawinan adalah ikatan sosial atau ikatan 
perjanjian hukum antar pribadi yang membentuk hubungan kekerabatan dan yang merupakan suatu pranata dalam budaya setempat yang meresmikan hubungan antar pribadi yang biasanya intim dan seksual. Perkawinan umumnya dimulai dan diresmikan dengan upacara pernikahan. Umumnya perkawinan dijalani dengan maksud untuk membentuk keluarga. Tergantung budaya setempat bentuk perkawinan bisa berbeda-beda dan tujuannya bisa berbeda-beda juga. Tapi umumnya perkawinan itu ekslusif dan mengenal konsep perselingkuhan sebagai pelanggaran terhadap perkawinan. Perkawinan umumnya dijalani dengan maksud untuk membentuk keluarga. Umumnya perkawinan harus diresmikan dengan pernikahan.

Poligami adalah sistem perkawinan yang salah satu pihak memiliki atau mengawini beberapa lawan jenisnya dalam waktu yang bersamaan. Dalam antropologi sosial, poligami merupakan praktik pernikahan kepada lebih dari satu suami atau istri (sesuai dengan jenis kelamin orang bersangkutan). Hal ini berlawanan dengan praktik monogami yang hanya memiliki satu suami atau istri. Terdapat tiga bentuk poligami, yaitu:

- Poligini merupakan sistem perkawinan yang membolehkan seorang pria memiliki beberapa wanita sebagai istrinya dalam waktu yang bersamaan.

- Poliandri adalah sistem perkawinan yang membolehkan seorang wanita mempunyai suami lebih dari satu orang dalam waktu yang bersamaan

- Pernikahan kelompok (bahasa Inggris: group marriage) yaitu kombinasi poligini dan poliandri.

Ketiga bentuk poligami tersebut ditemukan dalam sejarah, tetapi poligini merupakan bentuk yang paling umum terjadi. Walaupun diperbolehkan dalam beberapa kebudayaan, poligami ditentang oleh sebagian kalangan. Terutama kaum feminis menentang poligini, karena mereka menganggap poligini sebagai bentuk penindasan kepada kaum wanita.

\section{Pengertian Sanksi Adat dan Jenis-jenis Sanksi Adat}

Sanksi berasal dari bahasa Belanda yaitu Sanctie yang artinya ancaman hukuman, merupakan suatu alat pemaksa guna ditaatinya suatu kaidah, undang-undang misalnya sanksi terhadap pelanggaran suatu undang-undang.
Sanksi adalah tindakan-tindakan (hukuman) untuk memaksa seseorang menaati aturan atau menaati ketentuan undang-undang. Sanksi adalah alat pemaksa, dimana sanksi memaksa menegakkan hukum atau memaksa mengindahkan norma-norma hukum. Sanksi sebagai alat penegak hukum bisa juga terdiri atas kebatalan perbuatan yang merupakan pelanggaran hukum. Baik batal demi hukum maupun batal setelah ini dinyatakan oleh hakim.

Sanksi Adat adalah tindakan adat atas pelanggaran terhadap warganya sesuai aturan aturan yang telah disepakati yang biasanya tertuang dalam awig-awig desa adat sebagai pedoman dalam norma dan tata krama bermasyarakat sesuai dengan adat istiadat setempat. Dimana pada umumnya sanksi diberikan bertujuan agar tercapainya keseimbangan dalam masyarakat untuk dapat menciptakan kasukertan sekala-niskala (kedamaian lahir bathin). Menjatuhan sanksi terhadap pelanggar hukum adat umumnya tidak dilakukan secara semena-mena, tetapi sudah disyaratkan wenang mesor singgih manut ring kasisipan ipun (berat ringannya hukuman harus sesuai dengan tingkat kesalahannya atau pelanggarannya) yang dapat berupa nasehat, teguran ataupun peringatan atau istilah lainnya ngetuwel (membangkang) atas pelanggaran terkait awig-awig desa adat sebelum sanksi.

Dengan demikian, untuk dapat menghindari pengenaan sanksi tersebut yaitu disebutkan hendaknya kita dapat menjalankan norma bermasyarakat sehingga terciptalah seperti apa yang telah dicita-citakan untuk kebahagiaan setiap orang, masyarakat, maupun negara sebagai warisan yang luhur dalam kelestarian adat budaya masing-masing. Ada beragam sanksi adat yang bisa diberikan terhadap siapapun yang melakukan pelanggaran adat atau siapapun yang bersengketa.

\section{Lembaga “Karang Memadu” Sebagai Sanksi Adat}

Karang sendiri berarti tempat. Sedangkan Memadu artinya poligami. Sehingga Karang Memadu adalah sebutan untuk tempat bagi orang yang berpoligami. Karang Memadu adalah lahan kosong seluas $9 \times 21$ meter yang terletak di ujung selatan Desa Adat Penglipuran. Jika dilihat bentuknya, Karang Memadu tidak berbeda dengan lahan kosong pada umumnya. Hanya, untuk menandai lahan ini dipasang sebuah papan bertuliskan Karang Memadu yang tujuannya untuk membatasi lahan biasa dengan lahan 
khusus itu.

Warga Desa Penglipuran mempunyai 2 jenis hukum yang mereka taati dan ikuti yaitu AwigAwig (peraturan tertulis) dan Drestha (adat kebiasaan tak tertulis). Mayoritas penduduk melakukan pernikahan dengan sesama warga desa. Oleh sebab itu sebagian besar penduduk masih terikat hubungan darah antara satu sama lain. Jika terdapat laki-laki dari Desa Adat Penglipuran yang menikahi gadis dari keluarga di luar warga Penglipuran maka dia tetap harus melakukan kewajiban yang dimilikinya sebagai warga Desa Adat Penglipuran. Bagi para lelaki Penglipuran mempunyai lebih dari satu istri merupakan hal yang dilarang. Jika seseorang mempunyai lebih dari satu istri maka ia dan istriistrinya harus pindah dari Karang Kerti ke Karang Memadu (masih didalam desa tetapi bukan bagian utama). Hak dan kewajibannya sebagai warga Desa Adat Penglipuran juga akan dicabut. Setelah orang tersebut pindah, maka akan dibuatkan rumah oleh warga desa tetapi mereka tidak akan boleh melewati jalanan umum ataupun memasuki Pura dan mengikuti kegiatan adat. Ini merupakan bentuk penghormatan dan perlindungan terhadap kaum perempuan.

Orang yang Memadu juga tidak diizinkan untuk mengikuti sembahyang di pura-pura yang menjadi tanggung jawab desa adat. Tidak boleh juga bergaul di masyarakat dengan bebas. Dan satu lagi, pernikahan orang yang berpoligami tidak disahkan oleh desa. Sehingga, upacaranya tidak diselesaikan oleh pemimpin tertinggi di desa dalam pelaksanaan upacara adat dan agama. Itulah Karang Memadu yang secara tidak langsung mendidik kaum lelaki untuk setia terhadap satu pasangan saja. Hal ini juga menjadi bukti bahwa leluhur setempat sejak zaman dahulu memang sangat menjunjung tinggi dan menghormati keberadaan kaum wanita.

\section{Efektivitas Sanksi dan Teori Pengenaan Sanksi}

Sanksi adalah akibat suatu perbuatan atau suatu reaksi yang berupa hukuman dari pihak lain (manusia atau organisasi sosial) atas perbuatan. Sanksi pidana diartikan sebagai hukuman yang diberikan kepada seseorang yang kedapatan atau terbukti melakukan pelanggaran atau kekeliruan yang dapat menimbulkan ketidak tentraman masyarakat. Hukuman merupakan sanksi yang harus diterapkan pada setiap tindak pidana yang berupa suatu penderitaan bagi si terpidana dengan putusan atau vonis hakim, sebagai dari akibat perbuatannya yang jahat atau salah yang wujudnya baik dengan mengurangi atau mengambil kemerdekaan dirinya untuk bergerak di masyrakat ramai atau disitanya harta benda si pelaku dengan membayar sejumlah denda sebagai tebusan perbuatan tersebut. Hal itu dilakukan sebagai pencegahan agar orang lain tidak melakukan hal yang sama dengan. Sanksi pidana mempunyai tujuan yang terarah yaitu selain untuk melindungi masyarakat dari segala perbuatan jahat atau menyesatkan, menakut-nakuti mereka yang akan berbuat jahat atau yang akan melanggar hukum, yang terpenting adalah menginsyafkan, menyadarkan dan memperbaiki jiwa dan tingkah laku mereka yang terpidana. Ketiga tahap ini dilihat sebagai suatu usaha atau proses rasional yang sengaja direncanakan untuk mencapai tujuan tertentu dan merupakan suatu keterpaduan yang harus tercapai secara selaras dan seimbang. Kebijakan teori hukum pidana secara garis besar meliputi perencanaan atau kebijakan tentang sanksi atau penjatuhan pidana yang dikenakan terhadap pelaku kejahatan atau pelaku perbuatan terlarang baik berupa pidana ataupun tindakan dan sistem penerapan hukumnya.

Sanksi pidana tidak memiliki tujuan tersendiri yang harus ditemukan dalam dirinya sendiri. Sanksi tersebut dimaksudkan untuk memberikan perlindungan terhadap norma. Selama norma belum dilanggar, sanksi pidana hanya bersifat preventif. Seketika terjadi pelanggaran, daya kerjanya seketika berubah dan sekaligus menjadi represif. Berbicara mengenai tujuan pemidanaan, tentunya kita harus melihat teori-teori pemidanaan yang ada. Teori-teori pemidanaan dapat dibagi kedalam tiga golongan besar yaitu, teori pembalasan (teori absolut/distributif), teori tujuan (teori relatif), dan teori gabungan.

Teori pembalasan (absolut) dikatakan sama tuanya dengan awal pemikrian tentang pidana, namun demikian ajaran ini tidak ketinggalan zaman. Dasar dari teori ini adalah pembalasan. Inilah dasar pembenar dari penjatuhan penderitaan berupa pidana pada penjahat. Negara berhak menjatuhkan pidana karena penjahat tersebut telah melakukan penyerangan dan pemerkosaan kepada hak dan kepentingan hukum (probadi, masayrakat atau negara) yang telah dilindungi. Maka oleh karena itu ia harus diberikan pidana yang setimpal dengan perbuatan yang dilakukannya. Meskipun kecendurangn untuk membalas ini pada prinsipnya adalah suatu gejala yang normal akan tetapi pembalasan 
tersebut harus dilihat sebagai suatu reaksi keras yang bersifat emosional dan karena itu irasional. Karl O. Christiansen dalam (Usman, 2011) mengidentifikasi lima ciri pokok dari teori absolut yaitu :

Tujuan pidana hanyalah sebagai pembalasan

- Pembalasan adalah tujuan utama dan didalamnya tidak mengandung sarana-sarana untuk tujuan lain seperti kesejahteraan masyarakat

- Kesalahan moral sebagai satu-satunya syarat untuk pemidanaan

- Pidana harus disesuaikan dengan kesalahan si pelaku

- Pidana melihat ke belakang, ia sebagai pencelaan yang murni dan bertujuan tidak untuk memperbaiki, mendidik, dan meresosialisasi pelaku.

Teori absolut mengajarkan bahwa pidana diniscayakan oleh kejahatan yang terjadi dan sebab itu negara dengan satu dan lain cara mendapat pembenaran untuk menjatuhkan pidana. Pandangan berbeda ditemukan dalam ajaran teori tujuan (relatif). Pidana dalam konteks ajaran ini dipandang sebagai upaya atau sarana pembelaan diri. Dalama ajaran ini hubungan anatara ketidakadilan dan pidana bukanlah hubungan yang ditegaskan secara apriori. Hubungan antara keduanya dikaitkan dengan tujuan yang hendak dicapai oleh pidana yaitu pelrindungan kebendaan hukum dan penangkal ketidakadilan atau tertib di dalam masyarakat.

Yang terakhir yaitu teori gabungan yang mendasarkan pidana pada asas pembalasan dan asas pertahanan tata tertib masyarakat, dnegan kata lain dua alas an itu menjadi dasar penjatuhan pidana. Teori gabungan dapat dibedakan menjadi tiga golongan, yaitu :

- Teori gabungan yang mengutamakan pembalsan, tetapi pembalasan itu tidak boleh melampaui batas dari apa yang perlu dan cukup untuk dapat dipertahankannya tata tertib masyarakat.

- Teori gabungan yang mengutamakan perlindungan tata tertib masyarakat, tetapi penderitaan atas dijatuhinya pidana tidak boleh lebih berat daripada perbuatan yang dilakukan terpidana.

- Teori menggabungkan yang menganggap kedua asas tersebut harus dititikberatkan sama.

Pengaruh Sanksi Karang Memadu Terhadap Jumlah Pelaku Poligami di Desa Penglipuran

Selain memiliki budaya menghormati alam, penduduk desa Penglipuran Bangli juga memiliki budaya dan tradisi untuk menghormati wanita. Hal ini dengan adanya aturan desa yang melarang pria untuk melakukan poligami. Jika ketahuan melakukan poligami maka akan mendapatkan hukuman dikucilkan dari desa. Tepatnya adalah diasingkan ke Karang Memadu, yaitu kawasan yang hanya difungsikan sebagai tempat tinggal pelaku poligami. Desa Adat penglipuran melarang poligami, dengan alasan pemberdayaan perempuan. Jika ada yang melanggar aturan ini, maka akan dikucilkan dan dipaksa tinggal di kawasan Karang Memadu itu sebagai hukuman.

Dari pemberlakuan adat tersebut dapat diketahui bahwa masyarakat Desa Penglipuran sangat menghargai emansipasi wanita. Menurut sumber yang kami wawancarai belum ada satupun warga Desa Penglipuran yang menghuni Karang Memadu hingga saat ini. Mendengar jawaban tersebut semakin menguatkan bukti bahwa masyarakat Desa Penglipuran mematuhi warisan adat mereka dan menjunjung tinggi emansipasi wanita. Dengan demikian wanita di Desa Panglipuran telah mendapatkan haknya sebagai seorang istri untuk mendapatakan cinta dan kasih sayang suami secara utuh dengan tidak dibagi-bagi dengan istri suaminya yang lain. Wanita Desa Penglipuran adalah contoh sosok ideal istri yang diinginkan wanita lain.

\section{Pandangan Masyarakat Penglipuran Terhadap Sistem Perkawinan Poligami}

Menurut Agama Hindu yang masyarakat Desa Penglipuran anut poligami bukanlah sebuah harapan hidup manusia yang normal tetapi suatu kenyataan hidup bagi orang-orang tertentu yang karena karmanya tidak bisa menghindari poligami. Jika karma masa lalu harus berbuahkan poligami hal itu tidak dapat dihindari karena buah karma. Agama Hindu mengajarkan pada umatnya untuk sebisa mungkin menghindari poligami. Begitu juga dengan Desa Penglipuran yang melarang warganya untuk beroligami dan sebisa mungkin menghindari perbuatan poligami.

Lelaki Penglipuran diharuskan menerapkan hidup monogami yakni hanya memiliki seorang istri. Larangan berpoligami ini diatur dalam peraturan adat. Peraturan adat menyebutkan bahwa laki-laki Desa Penglipuran tidak 
diperbolehkan memiliki istri lebih dari satu. Jika ada laki-laki Desa Penglipuran yang sudah beristri yang merasa bisa berlaku adil dan menikahi wanita lain, maka lelaki tersebut akan dikucilkan di sebuah tempat yang diberi nama Karang Memadu. Karang artinya tempat dan memadu artinya berpoligami. Jadi, Karang Memadu merupakan sebutan untuk tempat bagi orang yang berpoligami.

Penduduk desa akan membuatkan penduduk desa yang melanggar sebuah gubuk/tempaat tingggal atau yang disebut Karang Memadu sebagai tempat tinggal bersama istrinya. Penduduk desa yang dihukum hanya boleh melintasi jalan-jalan tertentu di wilayah desa. Artinya, suami-istri ini ruang geraknya di desa akan terbatas. Dilarang melintasi utara perempatan desa. Selain itu suami istri Desa Penglipuran yang melanggar pergaulannya akan dibatasi, dan tidak bisa bergaul dengan warga Desa Penglipuran yang lain. Tidak hanya itu, pernikahan orang yang berpoligami upacaranya pernikahannya tidak dipimpin oleh pemimpin tertinggi di desa dalam pelaksanaan upacara adat dan agama. Tidak hanya itu, karena pernikahan itu dianggap tidak sah maka orang tersebut juga dilarang untuk bersembahyang di pura-pura yang menjadi tanggung jawab desa adat. Mereka hanya diperbolehkan sembahyang di tempat mereka sendiri. Tujuan didirikannya Karang Memadu tersebut diantaranya adalah untuk mencegah terjadinya poligami di Desa Penglipuran. Karang Memadu diharapkan dapat mendorong masyarakat Desa Penglipuran agar tidak berpoligami. Peraturan adat yang bersifat memaksa dan disertai sanksi yang tegas itu adalah bentuk penanggulangan terhadap perilaku yang dianggap tidak manusiawi dalam keyakinan mereka.

\section{SIMPULAN}

Setelah menguraiakan apa yang menjadi pembahasan dalam artikel ini maka dapat ditarik beberapa simpulan yaitu Pelaksanaan sanksi adat Karang Memadu di Desa Adat Penglipuran dilakukan melalui paruman Krama Adat Penglipuran dalam rangka pelaksanaan awig-awig desa adat. Diputuskan melalui "Sangkepan Desa" atau musyawarah untuk mencapai mufakat. Mempelai yang "memadu" berpoligami sudah menyadari akibat dari keberaniannya melakukan poligami yang oleh masyarakat setempat di anggap "Ngeregedin Desa" sehingga wajib untuk dikucilkan di tempat khusus jauh dari masyarakat pada umunya.

Tentang efektivitas penerapan "Sanksi Karang Memadu" bagi krama Desa Adat Penglipuran yang berani berpoligami, berdasar penelitian terbukti sangat efektif. Indikatornya adalah hampir sejak 31 Tahun, (sejak awig-awig Desa Adat Penglipuran ini dikukuhkan kembali tanggal 19 Agustus 1989) yang lalu, tidak ada satupun krama Desa Adat Penglipuran yang beranai melanggar ketentuan dilarang berpoligami. Terbukti sampai saat penelitian ini dilaksanakan, belum ada krama desa adat yang berniat melakukan poligami. Karena diketahui akibatnya adalah dikucilkan di kawasan "Karang Memadu".

Selanjutnya melihat fenomena tersebut maka penulis disini hendak memberikan beberapa saran yang kiranya dapat diperhatikan untuk membantu memecahkan masalah yang terjadi tersebut yaitu diantaranya kepada masyarakat Desa Adat Penglipuran hendaknya "Sanksi Adat" berupa kkearifan lokal ini terus dipertahankan karena terbukti mampu menjamin keharmonisan masyarakat dan ketentraman kaum Ibu-ibu yang tidak terancam dipoligami. Selain itu dapat diperhatikan kepada pengurus/Jero Bendesa, Desa Adat Penglipuran hendaknya semakin inten untuk mensosialisasikan kepada generasi muda tentang fenomena Sanksi Adat Karang Memadu mungkin dengan memasang banner dengan narasi bahwa, Karang Memadu adalah Sanksi Adat yang efektif menegaskan larangan berpoligami

\section{DAFTAR PUSTAKA}

Ardiani, Y. (2015). Karang Memadu Desa Penglipuran,Tradisi Yang Masih Terjaga. Retrieved from https://www.isi-dps.ac.id/ artikel/karang-memadu-desa-penglipurantradisi-yang-masih-terjaga/

Awig-awig Desa Adat Penglipuran Tahun 1989

Kasuma, I. P. A. W., \& Suprijanto, I. (2012). Karakteristik Ruang Tradisional Padadesa Adat Penglipuran, Bali. Jurnal Pemukiman, 7(1), 4050. Retrieved from http://dx.doi.org/10.31815/ jp.2012.7.40-50

Maharani, E. (2017). Karang Memadu, Areal Pengasingan Poligami di Bali. Retrieved from https://republika.co.id/berita/dunia-islam/islamnusantara/17/10/12/oxp413335-karang-memadu -areal-pengasingan-poligami-di-bali

Moelong. (2002). Metodologi Pengabdian Kualitatif. Bandung: Remaja Rosdakarya.

Sattwika, K. N., Sudibya, D. G., \& Ujianti, N. M. P. (2020). Penyediaan Karang Memadu Bagi Warga Yang Berpoligami Di Desa Adat Penglipuran Kabupaten Bangli. Jurnal 
Interpretasi Hukum, 1(1), 72-76. Retrieved from https://www.ejournal.warmadewa.ac.id/ index.php/juinhum/article/view/2189

Usman, H. (2011). Analisis Perkembangan Teori Hukum Pidana. Jurnal Ilmu Hukum Jambi, 2 (1), 62-78. Retrieved from https:// www.neliti.com/publications/43258/analisisperkembangan-teori-hukum-pidana\#cite 